\section{MP-37腎細胞癌培養細胞株における炭酸脱水酵素 アイソザイムの発現}

\section{高知医科大学 泌尿器科 \\ 高知医科大学 第一内科 ${ }^{2}$}

蘆田 真吾" 西森 功2"大西 “朗" 執印太郎”

【日的】炭酸脱水酵素, Carbonic Anhydrase (CA)アイソザイム CA9およびCA12はvon Hippel-Lindau (VHL) tumor suppressor geneによってdown-regulation学什ると報告されている。今回， 七卜腎癌培養細胞株に打いてCA9，12芯らに14の発現とVHL遺 伝子变異との関係について検討した。【対象と方法】ヒ卜腎癌培 養細胞株19株におけるCAの発現をノーザンブロット法を用いて 解析した。またVHL 遺伝子变異をダイレクトシークエンス法に て確認した。【結果】検討した細胞株においてCA9の発現は heterogeneousな発晲パターンを示したか，VHL 遺伝子変異がな く発現を認めるものが1株, VHL 遺伝子変異があるのに発現を 琹めないものが4株存在した。CA12にこいては発現の强弱はある 屯ののほ上んよ゙の細胞株において発現を認めた。VHL損腎癌 細胞株に打けるCA12の発現はこれにVHLを導入した細胞株にお いて咸弱していた。CA14についてはす心゙ての細胞株において発 現を認めなかった。【結論】今回のわ加われの検討でCAの発現 は必ずしもVHL 遺伝子変異上は関係ない事が示された。従って CAの発現には他のpathwayも関与している可能性が示唆された。

\section{腎細胞癌 炭酸脱水酵素 VHL}

\section{MP-39＼cjkstart腎細胞癌患者におけるacute-phase reactants, BFPおよびIAPについての臨床的検討}

\footnotetext{
長崎大学 医学部 泌尿器科”長崎大学 医学部附属病 院 病理部 ${ }^{23}$

容田康好" 古賀成彦" 錦戸 雅春 金武洋

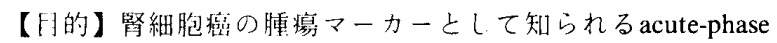
reactants(血沈, CRP 抢よびフェリチン)、basic fetoprotein(BFP)、 immunosuppressive acidic protein(IAP)の片清値について臨床病 期（Robson分類）および予後との関連につき検剖する。【対象 と方法】長崎人学医学部附属病院を1990年から1998年に受診した 患者のうち、上記の腫㷎マーカーを測定し得た 76 名（男性 62 名、女性 14 名、平均年齢60.3歳) を対象とした。各測定值は治 療前に測走した。【結果】BFPを除く4つの測定值は、臨床病期 および異型度を叹映していた。単変量解析による各腫瘍マーカー の证常群と、高值群における生存染の差をlog rank testでみると、 CRP、フェリチン扰よびIAPで有意差（ $(\mathrm{p}<0.05 ）$ を認めたが、血 沈扰よびBFPに関しては何意差至認めなかった。また、この5つ の腫瘍マーカーについて、stepwiseによる多変量解析を行なった ところ、フェリチンのみが独方因子であった（ハザード比=7.45、 95\% CI: 1.33-24.23、p=0.010)。しかし、このモデルに臨床病期 と翼型度を投人すると、臨床病期のみか独立因子となった（ハザ 一ト比 $=27.19 、 95 \% \mathrm{CI}: 2.13-267.57 、 \mathrm{p}=0.005)$ 。【結論】 今回検 討した範用では、血清フェリチン値が最も予後を反映していた。 しかし、それは臨床病期老超えるものてはなかった。
}

腎細胞癌 腫瘍マーカー 臨床的検討

\section{MP-38 非乳頭状腎細胞癌におけるFISH法による} 染色体3番短腕と8番短腕領域欠失の解析

\author{
山口大学 医学部 泌尿器科" \\ 小野田市立病院 泌尿器科27 \\ 山口史朗”吉弘悟"長尾一公" 福永捸: : " 松本洋明" \\ 松田 健二"大場一生"2 和田 尚" 内藤克輔"
}

【目的】非乳頭状腎細胞癌における染色体 3 箱知腕と8番短腕領域 欠失をFISH法を用いて解析し, 臨床的バラメーター上の関連に

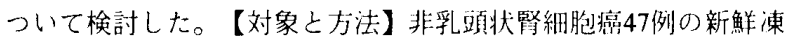
結標本より細胞をスライドグラスに屡開し, D3Z1 (3cen), cCl3-865 (3p25.5), D8Z2(8cen), cCl8-586(8p21.3), cCl8-588(8p21.1), cCI8-1045(8p12)のDNA probeを用いてFISH法を施行した。

【結果】3p25.5は31例 $(66.0 \%) ， 8 \mathrm{p} 12$ は25例 $(53.2 \%) ， 8 \mathrm{p} 21.1$ は 28例 (59.6\%)，8p21.3は22例（46.8\%）に矢失を認めたか $3 \mathrm{p}$ と $8 \mathrm{p}$ の欠失の間には有意な関連性は認めなかった。grade亡の関係で は, high grade症例で, $8 \mathrm{p} 21.1 の$ 欠失が有意に高頻度 $(\mathrm{p}<0.05)$

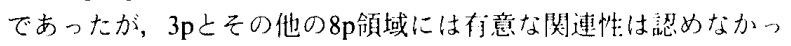
た。また $3 \mathrm{p}$ 执よび8pの欠失々stageとの関連性は認めなかった。 【結語】非乳頭状䝳細胞癌において，3pの欠失は高頻度に認める が臨床的パラメーター上は関連性はなかった。…j，8pの失失 （特に8p21.1）は, 組織学的異型度上有意に関連しておう，予後 を推測するgenetic markerとなりうる可能性が示唆された。

非乳頭状腎細胞癌 FISH法 染色体

\section{MP-40 腎細胞癌における腫葟組織内マクロファー ジの换討}

\section{埼玉医科大学 泌尿器科”}

濱田郁人“加藤 幹雄”山崎哲郎'岩㴊和明” 永島 弘登志" 岡田 耕市"

（目的）腫瘍関連マクロファージ（TAM）は腄瘍の発有、腄焬 血管新生など近年その影響についていくつかの癌で報皆されてい る。今回我々は腎細胞癌にてTAMの唡討を行ったので報先する。 (対象と方法) 腎細胞癌で腎摘约術を施行された50症例について 検索した。血管新生については第8 8 肉子に対する $\mathrm{mAb}$ 、マクロフ アージに対してはCD68抗原のmAbを朋いABC法にて検案し、そ れぞれの相関ならびに生命予後との関連につきKaplan-Meier法に て中央値で分別した2群で検㳡した。TAMは10視野中、最大数, 平均数,上位 3 つの平均数をそれぞれTAMmax, mean, mean 3 上した。 （結果）対象は男性 35 例,女性 15 例で、联均年命は56.3 才であ った。腫瘍新生血管数とTAMには強い相関（ $\mathbf{r}=0.80 \quad \mathbf{P}<0.001 ）$

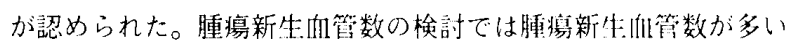
群で予後不良であった $(\mathbf{P}<0.05)$ 。TAM揖いてもTAMmaxの多 い群で不良となる倾向であった $(\mathbf{P}<0.10)$ 。さらに術前のCRP上 TAMには有意な正の相関（P<0.006）が見ら狆た。(考察) 蹩紐

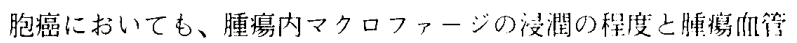

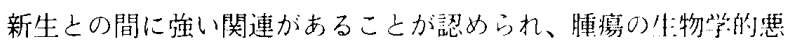
性度との関係が闹時に示唆された。

腎細胞癌 新生血管 腫瘍関連マクロファージ 